\title{
Vision and Imagination in the Renaissance Theatre
}

\author{
Carlo Fanelli \\ Università della Calabria, Arcavacata (CS), Italy
}

\begin{abstract}
To see what lacks representation on stage is a fully creative act that the spectator performs thanks to his or her imagination, as (s)he is called to retrieve via memory what is objectively absent from the scene. The Renaissance audience accomplished such a creative act by making use of rhetoric and figurative arts. However, it is pre-eminently words that trigger and support the imagination, as Shakespeare's drama best exemplifies. Both in the Elizabethan drama and in the Italian Renaissance theatre, with its perspectival vision, the spectator's creative act takes place in an ideal space where the stage space turns into the locus of stereoscopic vision. Consequently, the creation and consumption of the vision originates first and foremost in drama (comedy and tragedy). The psychological, aesthetic, and anthropological mechanisms at the heart of vision, and the fruition of the images deriving from words, can be found as operating within the dramatic text, from the point of view of both the playwright and of the spectator/listener, in a direct relationship of cause and effect. Religious and especially Jesuitical drama, whose theatrical experience aims at discovering a correspondence between words and images, testifies to the visual power of the theatre.
\end{abstract}

Keywords: imagination, vision, theatre, Renaissance, perspective scenery

That One for Whom no new thing can exist Fashioned this art of visible speech—so strange

To us who do not now it here on earth.

一Dante

Purgatory (1985).

\section{Introduction}

The present article wishes to propose a new theoretical approach to the interaction between the Renaissance theatre and the figurative culture of that age. Previous studies in this field have focused especially on the new ways of codifying the scenic space in the Renaissance. This study, instead, sets out to underscore the dramaturgical significance of the visual aspect in theatre.

In the first instance, the apparato, as sixteenth-century intellectuals defined it, is the ultimate heterotopic place (Foucault) which reflects the political hedonism proper of courtly theatre, in turn related to the imaginary city. This space is connected to utopia which, in turn, is realised on stage as an illusory space by means of painted props. Such a staging practice, which brings together figurative techniques and symbolism, is materially realised by overcoming the paratactic scenic structure, dating back to the middle ages, and by substituting it with a "syntactic" organisation of the scenic space based on a perspectival spatial dynamics.

Carlo Fanelli, Ph.D. in Italian Studies, Lecturer in Performing Arts, Dipartimento di Studi Umanistici, Università della Calabria. 
This new set-up imposes a frontal view of the play which celebrates the correspondence between the ideal spectator (the prince) and the performance (the ideal city). The interaction between the figurative dimension of the scene and its contribution to drama is realised through the union between the scenic space, which includes the places represented by the scenic design, and a series of figurative elements. These are absent from the scene but are evoked by the spectators' imagination, stimulated by the lines of the play. The intertwining of sight and imagination compounds the need for verisimilitude and mimesis with the idealisation of the court. The affinity between words and mental images is sustained by rhetoric, a powerful instrument for connecting language, images, and imagination. In addition to the rhetorical formulae proper of Renaissance theatre, mnemotechnics enables the spectator to see, through his/her imagination, the places that words evoke, which are necessary for the mimetic representation of the action on stage.

The present article will offer a number of examples with the aim to clarify the interconnection existing between words and images, functional to the onstage dynamics. It will demonstrate how such an intellectual apparatus is primarily an expression of the relationship between the spectacle and the spectator in sixteenth-century court, and how it will subsequently evolve to take on other forms in the Renaissance theatre, disconnected from its previous uses within courtly theatre.

\section{Seeing the Invisible}

It is midnight. On the ramparts of Elsinore the changing of the guard is ready. Barnardo turns to Francisco and says: "If you do meet Horatio and Marcellus, the rivals of my watch, bid them make haste" (Shakespeare, 1980, act I sc. I. 63). The soldiers about to begin their watch are the same who witnessed the ghost's apparition. But what did they really see? They certainly underwent a "visual experience", yet do they have to believe what they experienced by faith? Or, should they interpret what they saw as a demonic apparition? What does the ghost want to mean with its sudden apparition? The ghost, given its paradigmatic value, provides the starting point for our investigation. ${ }^{1}$ Barnardo and Francisco see or believe they have seen what the real excludes from their sight, that which cannot be seen in everyday life.

Also, Hamlet has pierced Polonius, who was hiding behind an arras, with his sword and is now going after his mother Gertrude. Suddenly, the ghost reappears and Hamlet asks his mother: "Hamlet: Do you see nothing there? Queen: Nothing at all. Yet all that is I see” (Shakespeare, 1980, act III, sc. IV, 151). The visual dynamics of this scene is also paramount for our argument. Polonius, who is hiding, is thus invisible to the eye, but visible in his physical presence and, more significantly, he becomes the instantiation of an antithesis: On the one hand, there Hamlet who displays an ability to see what others cannot see through an act of faith (he sees the ghost), on the other hand, there are those like Gertrude who can only see the actual and objective reality (and

\footnotetext{
${ }^{1}$ In the first chapter of De memoria Aristotele demonstrates how, from the connection between memory and phantasia, the creation of images occurs in the human mind. He then moves on to describe the phantasmaaseikòn, referring back to what he had affirmed in the De anima and underlining how images are necessary for the noein. As he writes in his On Memory: "The subject of presentation has been already considered in our work de Anima. Without a presentation intellectual activity is impossible, for there is, in such an activity, an incidental affection identical with one also incidental in geometrical demonstration. For in the latter case, though we do not for the purpose of the proof make any use of the fact that the quantity in the triangle (for example, which we have drawn) is determinate, we nevertheless draw it determinate in quantity. So likewise, when one exerts the intellect (e.g. on the subject of first principles), although the object may not be quantitative, one envisages it as quantitative, though he thinks it in abstraction from quantity; while on the other hand, if the object of the intellect is essentially of the class of things that are quantitative, but indeterminate, one envisages it as if it had a determinate quantity, though subsequently, in thinking it, he abstracts it from its determinateness. Why we cannot exercise the intellect on any object absolutely apart from the contiguous, or apply it even to non-temporal things in connection with time, is another question” (Aristotele, 1941, p. 608).
} 
therefore cannot see the ghost). Shakespeare thus presents us with two juxtaposing and conflicting intellectual and perceptive planes which are the expression of a different approach to seeing.

Precisely these opposite ways of seeing the world further foreground our study, since they hint at the possibility of seeing beyond that which is objectively visible thanks to an act of imagination. Such a theoretical perspective, because of its very essence, introduces the visual dialectics within the theatre and, specifically, within the Renaissance theatre. The reason why such a dynamics can be observed here derives from a series of allegorical references which concur to define the theatrical relation between the actors and the audience.

The encounter between the lieu of the opsis and a heuristic dimension characterises the Renaissance theatre as the locus of a holistic theatrical experience. At the heart of such an encounter is the condition of a member of the court who, like Prince Hamlet, is also a spectator. As a result, the theatre can be seen as a "heterotopia", 2 whose function converges within the political "apparatus" to which the performance taking place belongs. $^{3}$

By entering into a relationship with the stage space which is not solely visual, the audience is caught between an act of faith and a creative act. Although the stage is the place where that which is verisimilar is made real, such a vision can only occur thanks to an osmotic relationship between the scene in perspective and the audience's mental images. In particular, the urban places represented on stage are not inhabited by the actor alone, ${ }^{4}$ but lived by the audience through its imagination. The city, "imagined" on the stage recalls the actual city, and both the audience and the performance become functional elements of the "apparato".

What occurs recalls the prologue of Shakespeare's Henry $V$ where the chorus addresses the audience directly:
But pardon, gentles all,
The flat unraised spirits that hath dared
On this unworthy scaffold to bring forth
So great an object. Can this cockpit hold
The vasty fields of France? or may we cram
Within this wooden $\mathrm{O}$ the very casques

\footnotetext{
${ }^{2}$ According to Michel Foucault: "The heterotopia is capable of juxtaposing in a single real place several spaces, several sites that are in themselves incompatible. Thus it is that the theater brings onto the rectangle of the stage, one after the other, a whole series of places that are foreign to one another" (Foucault, 1984). Following Foucault, from a purely physical, material space, the stage can become a metaphorical place where symbolic meanings and mental images meet, conjured up by the allegorical nature of the performance.

${ }^{3}$ The "apparatus" is the one theorised by Foucault. The apparatus aims at controlling social customs, at containing free thought and manipulating social consensus. It is: "first and foremost, a thoroughly heterogeneous set consisting of discourses, institutions, architectural forms, regulatory decisions, laws, administrative measures, scientific statements, philosophical, moral, and philanthropic propositions [...] a formation, so to speak, that at a given historical moment has as its major function the response to urgency. The apparatus therefore has a dominant strategic function” (Foucault, 2009). Although Foucault applied the notion of "apparatus" to refer to the totalitarian regimes of the 20th century, one could apply his definition to the Renaissance court. The latter was based on a series of normative rhetorical and persuasive discourses which regulated the behaviour of the perfect courtier. Such rules applied to drama and the performing arts of those times as well, in that writers and playwrights used rhetoric as a guide to writing given the similarities existing between the structure of a speech and that of a dramatic text.

${ }^{4}$ Within this context, a significant passage can be found in the third Dialogue of the Quattro dialoghi in materia di rappresentazione scenica (1561) (Four Dialogues on Scenic Representation) by Leone di Sommi. Here the author, through his literary persona Veridico, explains: “è bene ridursi a ragionare più in mezzo et più in ripa al proscenio che sia possibile, sí per accostarsi il più che si può agl’uditori, come per iscostarsi quanto più sia possibile dalle prospettive della scena, poiché accostandolisi pèrdono del lor naturale, et il molto discostarsene par però poco a i veditori, come benissimo la esperienza ci mostra” (De Sommi, 1968, p. 258).
} 
That did affright the air at Agincourt?

$\mathrm{O}$, pardon! since a crooked figure may

Attest in little place a million;

And let us, ciphers to this great accompt,

On your imaginary forces work...

Suppose within the girdle of these walls

Are now confined two mighty monarchies,

Whose high upreared and abutting fronts

The perilous narrow ocean parts asunder.

Piece out our imperfections with your thoughts:

Into a thousand parts divide one man,

And make imaginary puissance.

Think, when we talk of horses, that you see them

Printing their proud hoofs I'th'receiving earth:

For 'tis your thoughts that now must deck our kings,

Carry them here and there: jumping o'er times;

Turning th'accomplishment of many years

Into an hour-glass: for the which supply,

Admit me Chorus to this history;

Who prologue-like your humble patience pray,

Gently to hear, kindly to judge, our play. (“exit”). (Shakespeare, 1955, Act 1, Sc. 1, 3-4)

The audience is invited to use its imagination to transcend the physical and temporal boundaries of the stage, while still considering its plausibility.

Those who look at the stage must be aware of the fictional character of the performance they will be watching: What their eyes cannot see is objectified through their imagination, in turn ignited by the same scene that the eyes are contemplating. The stage space thus becomes the place where both the bodies and the ghosts act simultaneously. However, in order for this to occur, the incorporeal nature of the mental images has to be one with the corporeal reality of the wood ("this wooden O") of which the stage and the entire theatre are made.

The tangible corporeality of the bodies and of the physical places onstage allows the audience to see beyond matter, beyond what is tangible and what is visible.

\section{Perspective Scenery and Stereopsis}

The dichotomy between seeing and imagining lays the basis for the affirmation of the perspective scenery in the Renaissance theatre and of the Renaissance as the "civilisation of seeing".

The perspective scenery in which the vision of the city is objectified results from the union of the new figurative canons revolutionised by Brunelleschi's perspective and the foundation of the modern theatre, codified by the so-called "three scenes" described by Sebastiano Serlio. ${ }^{5}$

The word, the image, and the architectural space merge to form a new theatrical code. This code is grounded in ancient tradition, but looks ahead towards the "new" world of which it becomes an expression and of the Renaissance court as well.

The celebratory and recreational apparatus of the theatre finds its utmost expression in the spectacular

\footnotetext{
${ }^{5}$ Codified and described in the chapters titled: Della scenacomica, Della scenatragica, Della scenasatirica, (On the Comic Scene, on the Tragic Scene, on the Satirical Scene) in Isettelibridell'architettura (The Seven Books of Architecture) Serlio published in Paris in 1545 .
} 
Festa, ${ }^{6}$ where the scenery takes on a "symbolic form" following what Erwin Panofsky theorises with reference to the "central perspective". This is an "infinite, unchanging and homogeneous space-in short a purely mathematical space”, conditioned by the visual perception which "does not know the concept of infinity”, and is represented on the stage as a limited, confined spatial entity (Panofsky, 1991, pp. 29-30).

Conceived following such mathematical and symbolic criteria, the perspective scenery is then divided into three areas: The first, which is close to the audience, coincides with the proscenium, can be accessed by the actors and is delimited by frontages on a 1:1 scale. The second part shows the frontages of the buildings from an angle and represents a street or a square. The actors do not access this area so as not to alter the symmetry between the buildings and the actors' height, by appearing taller than the buildings around them. The third is made up of a painted backdrop which closes the vanishing point of the street or of the square. The set of frescoes of the so-called Schifanoia cycle, ${ }^{7}$ which Aby Warburg attributes to Ferrara artist Pellegrino Prisciani (Warburg, 1966, pp. 263-264), constitutes the link between the dramatic and the artistic culture which led to such a theatrical "invention". Prisciani was the author of the most important humanistic Renaissance treaties, the Spectacula. The Ferrara frescoes provide a vivid testimony of the life of the dukedom in the age of Borso, when drama began to flourish. As Ludovico Zorzi has pointed out, through the analysis of some exemplary details of this pictorial cycle, one can observe the emergence of the idea of a city, albeit mutable and allusive, which, by linking us to our initial reflections on the actual shape of the city, allows us to envisage the "city” of Ferrara in a plausible, yet imperfect way. Such a city becomes the first of an autonomous typology of "city scene”, which will find its original development in the humanistic drama (Zorzi, 1977, p. 8). Moreover, following Zorzi, one can affirm that the figurative perspective of the frescoes resembles that of the stage, so that there is a movement from the stage to the city.

Compounding the Schifanoia frescoes, the so-called "Ideal City" appears in three well-known paintings in which utopian and celebratory concepts combine to offer an allegorical representation of the city. The myth of the city arises out of the philosophical reappraisal of both Aristotle and Plato. Indeed, the Renaissance classicism had elaborated the notion of the perfect State, governed by philosophers and scholars able to guarantee its economic, social, political, religious, and cultural wellbeing. Such a notion, in turn, led to a renewed interest in architecture and city planning as means to realise the idea of good government. In effect, the latter could only be implemented through the union of moral rectitude, and of the architectural accuracy that

\footnotetext{
${ }^{6}$ The festa is a mixture of politics, art, and social life which derives from the court's need for both recreation and self-celebration. As a display of power, the festa produces an apparato whose functioning involves both the city and the court. A festive apparato characterises every important event: a wedding, a crowning, the visit of a foreign king, and even the death of famous characters offers a justification for revelling. The festa, both in the way it is conceived and in its development, reveals a pre-eminently eulogistic character. The triumphal entry affects the entire city. Following an articulated, symbolic programme, and route, the guest authorities enter the city following an itinerary carefully planned to exalt and emphasise their presence.

A luscious cortège used to parade through the streets upon which props with a strong political and cultural meaning, and a considerable architectural value, are located, such as the fake arcades having the same function as the Roman triumphal arches used to celebrate the war victories. Allegories inspired by the classic mythology and the Latin culture are employed, in which the symbolic dichotomies Virtue-Fortune, Love-Hate are present. These allegories reflect the iconographic symbols of the time and will eventually give rise to the theatrical practice of the interlude. Subsequently, the revel proper takes place in the prince's palace during which the theatrical performance is staged, and which is destined to the court only. On the features of the Renaissance festa, see: Attolini (1988), pp. 24-30. Cruciani (1986), pp. 31-45; Ferroni (1986), pp. 177-188; and Gareffi (1991).

${ }^{7}$ Warbug explains the symbolic dyad of the Ferrara frescoes, a pictorial cycle which appears to be connected to drama: In the upper part of the fresco, the celestial one, the symbolic images of pagan divinities reveal an allegorical predilection for the interludes of the Renaissance plays. In the lower part the depiction of the court that of the stage, see Warburg A. (1966), pp. 251-252. Furthermore, as Zorzi argued, "Il tipo di città partecipa della qualità dei tre ordini, passando dalla città reale alla città simbolica alla città immaginaria” (Zorzi, 1977, p. 9).
} 
was the latter's expression.

A predilection for harmony was supported by the application of the figurative principle of the linear perspective, described by Brunelleschi in 1421, and codified in Leon Battista Alberti's De Pictura. Their studies drew from the need to redefine the urban space on the basis of the anthropocentric view that placed man at the centre of the world and of the city. It was such a view that informed Alberti's work, De Re Aedificatoria, where he focuses on the city and on theatres. Here, he reinvents the way in which a city should be planned by envisaging a harmonious space where, drawing on the Roman architect Vitruvius, the social and economic life of the city could take place. He also refers to the theoretical paradigm of decorum linked to the rhetoric of civil life, which was one of the founding principles of the Renaissance culture and the foundation for the self-celebratory practices of the Renaissance court.

It was precisely this environment, and specifically that of the Urbino court, that originated the figurative tradition of the "Ideal City" paintings, which were completed at the end of fifteenth century. These three paintings, whose artists are still unknown, are named after the place in which they are preserved. The first is the so-called Urbino painting, the second is the Baltimore one and the third is the Berlin painting. All the three paintings depict the civil and religious architectural template invented by Alberti, although some attempts have been made to identify the city in the Urbino painting with Firenze and that in the Baltimore one with Rome.

In 1948 Rudolph Krautheimer contended that these paintings were an attempt to give visual representation to Vitruvius' theories on the scenery, and he hypothesised that they were used as flats proper of fifteenth and sixteenth century drama (Krautheimer, 1948, pp. 327-346), only to reject this theory some years later (Krautheimer, 1994, pp. 233-257).

Thus, following such theoretical assumptions, since its very inception, the Renaissance theatre, characterised itself as "a place of phantasmatic apparitions", grounded in the Aristotelian model and in the visual culture of its times. Some examples from some Renaissance dramas will show how an urge to construct an intimate theatre of the mind is at the heart of sixteenth century drama.

As a result, a double dynamics marks the relationship between actors and audience so that, in addition to the customary frontal way of consuming the performance, a circular mode of consumption is added. This circularity results precisely from the celebratory and self-reflexive nature of courtly drama, where the scene and the prince watching the performance are reflections one of the other.

The literary contents of the play serve an encomiastic purpose by placing both the prince and the scene on the same representational plane. One is a mirror of the other, in a play of symbolic references whose purpose is the celebration of courtly drama.

\section{Words as Images}

Greek and Latin plays and tragedies are the foundations of fifteenth and sixteenth century drama, which follows the norms dictated by Aristotle and Horatio, and of rhetoric, understood as the art of good speech and behaviour.

It is through mimesis that drama acquires its verisimilitude, which is the necessary element for the emblematic instruments of the mis-en-scene. This is particularly true of comedy, where everyday life is depicted as it is, and which offers the audience a moral lesson, in spite of the vices and virtues displayed. At the same time, language, governed by the dictates of rhetoric, guarantees the fusion between the need for verisimilitude and the need to be "appropriate for its context". 
Cicero and Quintilian's writings become the archetypes for the theme of the decorum and the logic of docere, moveredelectare (to teach to please and to persuade) which offer precious rules to the court and to its drama.

Aristotle's Poetics had already preconized the visual contribution to the written word:

In constructing the plot and working it out with the proper diction, the poet should place the scene, as far as possible, before his eyes.

In this way, seeing everything with the utmost vividness, as if he were a spectator of the action, he will discover what is in keeping with it, and be most unlikely to overlook inconsistencies. ${ }^{8}$

Here Aristotle formulates the visual principle of writing, and voices the need to use words to construct mental images. The process foregrounding such a construction must begin with the invention of facts: The poet has to envision the actions that characters perform according to the principle of verisimilitude; therefore, any choice that is inconsistent with the context of the play has to be avoided.

Imagination holds a fundamental place in Aristotle's Rhetoric, and such a concept echoes in a series of Renaissances treaties which draw the same conclusions. More generally, Aristotle attempts to define an iconic model of memory and thought useful for describing their mechanism.

Quintilian draws on Aristotle’s visual rhetoric, affirming that "we cannot imagine a speech without we also imagine a person to utter it [...] It is also convenient at times to pretend that we have before our eyes the images of things, persons or [...]."9 Memory sustains improvisation which, for Quintilian, acts as the privileged "transmitting agent" of "what it has received from the imagination". ${ }^{10}$ In the Renaissance, the art of memory or mnemotechnics will give primacy to memory and will find realization especially in the so called “Theatre of Memory” by philosopher Giulio Camillo Dalminio. ${ }^{11}$ This new way of conceiving the theatre

${ }^{8}$ Poe. 17 , 1455a.from http://classics.mit.edu/Aristotle/poetics.1.1.html.

${ }^{9}$ See Quintilian (1968), Vol. III, Book IX, ch. 2, pp. 32-33; 393.

${ }^{10}$ See Quintilian (1968), Vol. III, Book XI, ch. 2, 3, pp. 156, 158.

11 The method that Quintilian describes anticipates the art of memory ormnemotechnics as the described in The Idea of the Theatre by Giulio Camillo Dalminio (published posthumously in Venice in 1550). According to Quintilian "it is an assistance to the memory if localities are sharply impressed upon the mind, a view the truth of which everyone may realise by practical experiment. For when we return to a place after considerable absence, we not merely recognise the place itself, but remember things that we did there, and recall the persons whom we met and even the unuttered thoughts which passed through our minds when we were there before. Thus, as in most cases, art originates in experiment. Some place is chosen of the largest possible extent and characterised by the utmost possible variety, such as a spacious house divided into a number of rooms. Everything of note therein is carefully committed to the memory, in order that the thought may be enabled to run through all the details without let or hindrance. And undoubtedly the first task is to secure that there shall be no delay in finding any single detail, since an idea which is to lead by association to some other idea requires to be fixed in the mind with more than ordinary certitude. The next step is to distinguish something which has been written down or merely thought of by some particular symbol which will serve to jog the memory; this symbol may have reference to the subject as a whole, it may, for example, be drawn from navigation, warfare, etc., or it may, on the other hand, be found in some particular word. (For even in cases of forgetfulness one single word will serve to restore the memory.) However, let us suppose that the symbol is drawn from navigation, as, for instance, an anchor; or from warfare, as, for example, some weapon. These symbols are then arranged as follows. The first thought is placed, as it were, in the forecourt; the second, let us say, in the living-room; the remainders are placed in due order all round the impluvium and entrusted not merely to bedrooms and parlours, but even to the care of statues and the like. This done, as soon as the memory of the facts requires to be revived, all these places are visited in turn and the various deposits are demanded from their custodians, as the sight of each recalls the respective details. Consequently, however large the number of these which it is required to remember, all are linked one to the other like dancers hand in hand, and there can be no mistake since they join what precedes to what follows, no trouble being required except the preliminary labour of committing the various points to memory. What I have spoken of as being done in a house, can equally well be done in connexion with public buildings, a long journey, the ramparts of a city, or even pictures. Or we may even imagine such places to ourselves. We require, therefore, places, real or imaginary, and images or symbols, which we must, of course, invent for ourselves. By images I mean the words by which we distinguish the things which we have to learn by heart: in fact, as Cicero says, we use 'places like wax tabletsand symbols in lieu of letters'” (Quintilian, 1968, Vol. IV, Book XI, ch. 2, pp. 17-21, 165-167). 
uprooted the frontal relationship with the spectator, who is now placed centre-stage and surrounded by all the elements of the play. This way of envisaging the theatre was functional to the idea of an edifice of memory (whose realisation was quite unlikely) which would contain a full-fledged encyclopaedia of knowledge, organised and divided into separate but connected levels marked by images, inspired by Pico della Mirandola's hermetic and cabalistic philosophy.

The most interesting aspect of Dalminio's controversial Idea of the Theatre is his relationship with the theatrical visual dynamics, which focuses on the spectator centre-stage. Such a dynamics recalls the self-reflexive centrality proper of courtly theatre and the latter's visual mechanism in which, as pointed out earlier, the spectator is not simply a consumer of images, but actively participates in their creation. The spectator positions himself or herself not simply physically, but imaginatively, sensibly and intellectually, in relation to the stage.

The act of envisaging the action that the characters perform as theorised by Aristotle, finds correspondence in the treaties of the most important Renaissance scholars.

Angelo Ingegneri, in his Della poesia rappresentativa e del modo di rappresentare le favole sceniche (Ferrara, 1598), argues:

Converrebbe adunque che il poeta, il quale si dà a fare alcuna opera drammatica, primariamente si figurasse dinnanzi agli occhi la scena, divisandone fra sé gli edifici, le prospettive, le strade, il proscenio e ogn'altra cosa opportuna per l'avvenimento di quel caso ch'ei si prende ad imitare; e ne facesse nella sua mente propia una tal prattica, che non uscisse personaggio, che non gli sembrasse vedere ond'ei si venisse, né si facesse sul detto proscenio gesto, né vi dicesse parola ch'egli in certo modo no 'l vedesse e non la udisse. (Ingegneri, 1974, p. 95)

Similarly, Gian Giorgio Trissino, in his Sei divisioni della poetica (written in 1529 but published in 1562) comes to the conclusion that the poet:

dico che dee considerare che la tragedia che scrive debbia essere recitata, e veduti i gesti, e uditi i sermoni, e la melodia di essi. La onde dee trattare la favola con parole belle e accomodate; e nel costruirla, si de' ponere ogni cosa davanti gli occhi, e fare come se egli stesso fosse intervenuto in quelle azioni [...] e ponendosi quanto li sarà possibile avanti gli occhi i gesti e le figure che fanno quelli, che sono le passioni, si ponerà quasi in esse. (Trissino, 1969, pp. 36-37)

Thus the poet, in the act of writing the text, has to imagine how the scene will be staged, and has to "see" and "hear" the actors moving and speaking as they interpret their characters (Trissino, 1969, p. 138). This has to occur within the context of the stage and of the staging canons.

The figurative (representational and iconographic) process set in motion by imagination foregrounds the "apparato", a term which, in the majority of fifteen century commentaries, defines the entire performance, thus not just the scenery, the costumes, the make-up and so on. The term derives from the Latin apparatus which, in turn, is a rendition of the Greek opsis introduced by Aristotle. However, in the more current versions of Aristotle’s Poetics, the term "spectacle” has supplanted the term “apparato" (Guidotti, 2002, p. 36).

As far as some plays are concerned, one can observe that especially the dialogues in the comedies work to trigger the imagination. Machiavelli's The Mandrake Root provides one of the most significant examples of the ways in which such a process occurs.

Iddio vi salvi, benigni uditori, / Quando e’ par che dependa / Questa benignità da lo esser grato. / Se voi seguite di non far romori, // Noi vogliam che s'intenda / Un nuovo caso in questa terra nato. / Vedete l'apparato, / Qual or vi si dimostra: / Questa è Firenze vostra, // Un’altra volta sarà Roma, o Pisa, / Cosa da smascellarsi delle risa. / Quell’uscio, che mi è qui in sulla man ritta, / La casa è d'un dottore, / Che 'mparò in sul Buezio legge assai; // Quella via, che è colà in quel canto fitta, 
/ È la via dello Amore, / Dove chi casca non si rizza mai. / Conoscer poi potrai / All'abito d’un Frate // Qual Priore o Abbate / Abita el tempio che all'incontro è posto, / Se di qui non ti parti troppo tosto. (Machiavelli, 2001, pp. 66-67)

A similar visual plane can be found in the second prologue of the Calandria, ${ }^{12}$ whose intrinsically visual nature renders this comedy apt to guide the reader-spectator through an intellectual journey which brushes on to the oneiric dimension. It is a gentle, lively mental journey through a lunar, urban space which moves through words oozing images. The slightly malicious eye of the spectator visits such a place which, in a nocturnal and soft atmosphere, secretly reveals feminine virtues and whims, where the touch of the pictorial Renaissance "sprezzatura" is uncovered, the delicate yet not disenchanted comical expression, kept in check by the courtly decorum. This is a text that only hints at drama, but which by placing itself within an urban context, opens to wider and more universal speculations, which resemble allegory and divertissement. The subject of the Prologue is an imaginary flight over Florence that the protagonist carries out while dreaming of finding: "l'anel d'Angelica [...] che chi portava in bocca non poteva esser veduto di persona”, and thanks to such a power he is able to "andar del tutto senza esser veduto" and to move "invisibile alla casse di certi pigoloni avaracci [...] e vedere tutte le donne di Firenze quando si levano". ${ }^{13}$

This is not an original theme, as it recalls both Ariosto's and Boiardo’s poems of chivalry. ${ }^{14}$

The theme of the imaginary flight and of the dream, very popular in the fifteenth century, returns in Antonfrancesco Doni’s Marmi (1552), and earlier, in the prologue of Pietro Aretino’s Talanta (1542).

In the introduction to his collection, Doni presents the: "svegliato academico peregrino [...] uscito dal sonno [...] in volo in aria, sopra una città [...] diventato un uccellaccio grande grande che vegga con una sottil vista ogni cosa che vi si fa dentro" and crosses the skies of Naples, Rome, Venice and, finally, Florence. Here, he says, "nello svolazzare per aere, invisibilmente, m'arreco aliando sopra di loro, e ascolto e veggio tutti i lor fatti e ragionamenti [...] novelle, stratagemmi, favole [...] ragionamenti" which will eventually be the subjects of his novellas.

Similarly, the protagonist of the Prologue of Talanta narrates of "stato portato in Cielo e che qui le Stell gli hanno offerto la possibilità di poter diventare un Dio a propria scelta” and to have been turned into a cupid. In such a guise, after listing a number of divine virtues and foibles, he offers a tirade on the way men behave with women, by repeatedly using the pronoun "chi” (who $)^{15}$, as it also occurs, to a smaller extent, in Doni's work. ${ }^{16}$ Indeed, all these texts use irony to point at, and moralise on, the vices of both the men and women they present.

The relationship between invisibility and sight in the narrative is paramount from a mimetic, kinetic, and

\footnotetext{
12 The one notoriously attributed to Bibbiena, considered "lost" and then found by Isidoro del Lungo in 1875. A true experiment in mnemotechnics, for which see Fanelli (2012).

13 Calandria, Prologo del Bibbiena, in Padoan, G. (1985), p. 189.

${ }^{14}$ As already highlighted by Padoan G. (1985), p. 189

15 “Insomma, venutosi in sul caso di Ser Cupido, ci diedi subito il seì, e dandocelo mi sentii l'ale a le spalle, il turcasso al fianco e l'arco in mano; e così io già tutto ferro e tutto fuoco, desideroso di sapere ciò che si fa in amore, do d'una occhiata a le turbe che amano; onde veggo chi ha la posta, chi e piantato, chi si raggira intorno a la casa de l'amica, chi v'entra per la dritta, chi si aggrappa per le mura, chi vi monta con la scala di corda, chi salta de le finestre, chi s'asconde in una botte, chi e scoperto dal bastone, chi castrato dal coltello, chi e mezzo in ambra da la fante, chi trattone dal famiglio, chi arrabbia di martello, chi crepa di passione, chi si consuma spettando, chi fa le fica a la speranza, chi non se ne vuol chiarire, chi dona a la sua donna per grandezza, chi le toglie per impeto, chi la tenta con minacce, chi la scongiura con preghi, chi divulga il fine ottenuto, ,chi non confessa il suo gaudio, chi si vanta de la bugia, chi dissimula la veritade, chi celebra il soggetto che l'arde, chi vitupera la cagione che l'ha infiammato, chi non mangia per dispiacere, chi non dorme per letizia, chi compone versi, chi scribacchia pistole, chi sperimenta incanti, chi rinnova imprese, chi consulta con le ruffiane, chi si lega al braccio un favore, chi basciucchia il fioretto tocco da la manza, chi strimpella il liuto, chi biscanta un monetto, chi assalta il rivale, chi e ucciso dagli emuli, chi si cruccia per una madonna e chi spasima per una baldracca” Aretino P. (2010), p. 450.

16 “[...] chi nella sua casa piange, chi ride, chi partorisce, chigenera, chi legge, chi scrive [...]” (Doni, 1928, Vol. I, p. 3).
} 
semantic point of view. The imaginary dimension, within which the tale of the prologue is inserted, produces a dislocation and, to an extent, annuls the spatial-temporal dimensions characterising the action.

The imaginary act of flying breaks the stillness of the narrative; furthermore, "il comico, l'ironia o l'assurdo scaturiscono dallo stravolgimento delle dimensioni spaziali: lunghezze, o altezze inverosimili di cose o esseri animati, ovvero distanze abnormi” (Doni, 1928, XLI).

The spectator shares the ability to move as the narrative ignites and supports his or her imagination. The narrator of the prologue and the spectator meet in a fictional place they share, a place whose spatio-temporality is moulded by the tale. In so doing, the scrutinising and moralising eye of the spectator can extend and see what would otherwise be invisible and reconstruct the spatial and mimetic nature of the scene.

The prologue of the second edition of the Necromancer uses the ironic expedient, of classical inspiration, of a mental collaboration with the audience, who is invited to identify the city on stage, which was Ferrara in the previous representation of La Lena, with Cremona.

Ruzante deploys the same device in the prologue of Moschetta, staged in the same place a few days later, during the Carnival of 1529: “E questache è chialò no è Cremona né Ferrara: mol’èPava. E non v’in maravegiè se l’è pízola, perché l'havo giù an ela frezare a vegnir chialò”. Moschetta is set in Padua. This indicates that the three comedies had been represented in Ferrara using the same backdrop (Zorzi, 1977, p. 30). Also, in one of his works, Beolco constructs his narrative on the visual power of the word, even when he makes use of an excellent model such as Erasmus'. Indeed, Ruzante bases the couple Ruzante-Menato in his Parlamento on the two protagonists of the Erasmus' Militaria, Hanno and Trasymachus. The association between Ruzante-Trasymachus and Menato-Hanno, is inevitable, and so is the complementarity of the narrative scheme. The two soldiers, returning from the war in tatters and defeated, are dogged by those who ask fastidious questions on the battle, the slaughter, and their behaviour on the battlefield. In addition to an extraordinary "visual" ability to make the audience see the war through their tales, the two protagonists also share the need to recuperate what they left behind when they departed for the war and to return to a normal life. Beolco uses a device he takes from a line by Ruzante in Scene 1 of Parlamento which includes the dream:

S'a' m'insuinasse? La sarae ben de porco! A' sé ben ch’à no m'insunio, po. Non sogiemontà in barca a Lizafusina? A' son stò pur a Santa Maria d'un bel Fantin a desfarelmevò. Se mimo non fosse mi? e che a'foessestòamazò in campo? e che a'foesseel me spirito? La sarae ben bela. No, cancaro! Spiriti no magna. A son mi, e sì a' son vivo; cossìsaesse on' catar adesso la mia Gnua, o me compare Menato, che a’ sé l'è an elochì a le Veniesie. ${ }^{17}$

This is not an isolated expedient in the Renaissance drama; in fact, it has been frequently used to complete those scenes and images whose accuracy was limited by the lack of technological devices on the stage, and which follows the same procedure of the mnemotechnics. Thanks to the "mental" images the actors describe, the audience can overcome the physical boundaries of the scene to include images, places, sounds, and figures that could otherwise be formally shown.

\section{The World and the Universe in Giordano Bruno's The Candle Bearer}

The scene set in the city, proper of the Renaissance theatre, acquires a new anthropological and metaphysical dimension in Giordano Bruno's The Candle Bearer. Bruno wants to offer a new form of representation capable of uprooting the consolidated tradition of fifteenth century erudite theatre. Indeed, instead of a eurhythmic

${ }^{17}$ Ruzante (1967), Teatro, a c. di L. Zorzi, Einaudi, Torino, p. 519. 
evocation of the city and of a small number of places in which the action occurs, he multiplies the number of places thus exalting the multifaceted nature of the city and its toponymical and anthropological richness.

Bruno uses visual multiplication to describe the inhumane humanity, to offer a "nuova visione del mondo" which finds its reflection in a wordly theatre, through its characters, the varied nature of his works, and the rich socio-cultural context from which his oeuvre emerges. ${ }^{18}$

The multiple loci that Bruno's comedy evokes allow a direct connection between the actual urban world and the fictional world of the stage, from where the philosopher professes his beliefs. The multiplication of the visual planes compounds the moral perspective, in a play of shadow-light, day-night, knowledge and ignorance, life and death.

The physical and metaphysical spaces overlap completely. The multiple perspectives of Bruno's images uproot the utopian and neoplatonic conception of the Renaissance city instantiated by the paintings of the "Ideal City”, where harmony and order govern everyday life.

Instead, in The Candle Bearer, Bruno evokes "un barconaccio dismesso, scasciato, rotto, mal'impeciato [...] per forza tirato dal profondo abisso" which represents the cosmic chaos he evokes in his De umbrisidearum, published in Paris. Bruno "shrinks" the universe so that it fits the stage and makes the city of Naples its symbol. The chaos proper of the city informs a comic text which is "volutamente mostruoso e deforme, quale metafora di un mondo deformato, fatto di pungente delirio verbale, sordidezza, goffaggine, vizi e soprusi, dove tutto è capovolto, dal sublime della passione amorosa all'ansia per la ricerca scientifica e il linguaggio" (Sabbatino, 1998, pp. 39-40).

"La scena invade il mondo e il mondo si trasforma in scena. Finzione e realtà si intrecciano, si sovrappongono, si confondono" (Bruno, 2004, p. 61); within such a purview the world that Bruno portrays on stage is not dissimilar from the real one: in fact, it complements it and takes part in it, while aspiring to the universal. Bruno's theatre recalls the active and speculative function of Jesuitical theatre, where both the audience and the performers are brought together in their contemplation of the divine.

Through a series of internal references to Bruno's philosophical works, the visual dimension of The Candle Bearer again draws on the subject matter of both De umbrisidearum and Cantuscircaeus, the mnemotechnic work also published in Paris in 1582, in which the visual journey aims at dispelling the shadows of the ideas. Here Bruno establishes the principle whereby "to know means 'to see'” so that it is possible to understand the essence of the elements despite their initial complexity. This is what the spectator is called upon doing in order to discern the real essence of the human race.

Thus, through the metaphor of the painter, the subject matter of The Candle Bearer resembles that of The Heroic Frenzies, a work based on the visual metaphors of the "simulacro", of the "specchio", of "vestigio", and the "ombra", which all work to express mankind's inability to access knowledge directly. Knowledge can only be attained "nel riflesso delle cose naturali [...] nell'universo infinito", through images which render that which is invisible visible (Bruno, 2004, pp. 146-147).

Only through seeing can knowledge be attained, according to Bruno, who was influenced by ancient theories on knowledge. This principle informs the comic poetics of The Candle Bearer, where the object of the

\footnotetext{
${ }^{18}$ Such a totality produces the "Abolizione dei confini nella cosmologia, negazione della barriere nella poetica, abbattimento degli steccati nella gnoseologia commistione fra i saperi”, which is the essence of Bruno's thought, as Nuccio Ordine writes in Introduzione a Bruno G. (2004), Opere italiane, a cura di N. Ordine, 2 vol., p. 35.
} 
gaze is the world turned upside down by chaos. ${ }^{19}$ The references here are to the Platonic myth of the cave, but also to the origins of painting.

By being grounded in sentience as knowledge, whether in the light or in the darkness, the act of seeing can only occur either through scientific knowledge or by projecting towards the divine. In both cases, those who undertake such a journey travel from the outer world to the inner world, and from seeing to knowing.

\section{Tragic Imaginary}

The theme of "seeing" is widely used in fifteenth century comedies. It becomes a functional narrative resource in tragedy, where Cicero and Seneca's gnomical tradition and Ficino's neoplatonic visionary theories are also employed in order to support the horror necessary for activating the moralising tension at the heart of the Renaissance tragedy.

The horror and the macabre of Seneca's tragedies find actualization in the fifteenth century tragic canon, influenced by political, social, religious, and historical beliefs.

The transformation of the Renaissance tragedy occurs thanks to a rationalist impulse and to a prominent visual character, in the attempt to transcend the limitations of the fixed and perspective scenery so as to enable the representation of the exotic and of places and events "in motion".

The theatrical mechanism is premised upon the only apparently irrational correspondence between the ability to hallucinate and the rational unfolding of the play. The visual and aural stimuli at the heart of the performance, although deriving from mnemotechnics, reflect the didactic need of drama and of scenic realism; they become useful tools for reconstituting the temporality of the fabula, which coincides with that of the spectator.

As Marco Ariani has argued in relation to Rucellai’s Oreste,

La pluralità delle voci, l’angosciosa ossessione dei piani visivi che si intrecciano (il commento del Coro, la gestualità rituale, il pathos dell'amicizia, la sofferenza della vittima), la cantilena allucinata dei settenari di netta impronta melica (le anfore, le riprese, le rime) riescono a creare un incubo che deforma la situazione tragica in uno struggimento tortuoso e commotivo, in uno sgretolarsi dell'azione in un languore lacerato e insieme lezioso. (Ariani, 1974, p. 81)

Other works of that age offer significant example of such mechanisms. The character of "Ombra" in Orbecche and in Canace, and that of "Voce" in Orazia impose the dematerialisation of the character, who is replaced by an incorporeal entity aspiring to a visionary immateriality. The aim is a will to express deeper metaphysical meanings, which detach from the immediacy of the canonical function on stage in order to gain a deeper, more efficient, more meaningful inner and allusive ability to signify.

Such an aspiration explains the continuous invitations to "see", that is, to grasp with the eyes, the mind and the soul, the actual places reproduced onstage. Such an invitation can be found in the Prologue of Giraldi Cintio’s Selene:

Ora pensate di trovarvi n Tebe... / E, se non sete in lei con la persona, / Siatevi con la mente e col pensiero» e come pure il Prologo della Selene riporta in chiusura: «E benché 'n Alessandria, ch’è 'n Egitto, / Venga questo soccesso, e sia lontana / Questa città d ala cittade vostra, / Il poeta, per men vostro disagio, / Insensibilmente con nova arte / Vi ha tutti insieme a lei fatti condurre. / E se nol mi credete, / alzate gli occhi / A questo almo paese ch'io v'addito, / E vi vedrete senza muover piede / Giunti tutti in un punto in Alessandria. (Giraldi Cintio, 1996, pp. 3-4)

The tendency to depict actual things on stage, unlike the motionlessness of the written page, engages the

\footnotetext{
${ }^{19}$ One is reminded of Hieronimus Bosh and Petr Brueghel's pictorial "hallucinations" representing chaos as opposed to the perspectival (and cold) rationalism of the "Ideal city" paintings. Such a comparison bridges the early southern and insular culture with the northern cosmopolitan one, following the itinerary of Bruno's philosophical thought from Naples to France and England.
} 
spectator's sense perceptions and becomes a fundamental element in the staging process, highlighting the interdependence between fabula and scenic design .The treaties of the time offer a number of norms for this function. As Ludovico Castelvetro advises:

Ma ponente che l'argomentare della vista al ballo, o dal ballo alla vista per dimostrare la gravezza o la leggerezza della tragedia non è uguale ne lodevole. Perciocché la vista quando è convenevole non è di soprappeso alla tragedia, ma parte necessaria, e anzi leggerezza che nò, ma il ballo quantunque sia convenevole è sempre di soprapeso alla tragedia, e parte superflua, e di gravezza. (Castelvetro, 1967, p. 378)

Here, he follows Aristotle's recommendations, which remain the foundations for every Renaissance writer. There is a need to expand the scenic space beyond the material, by including spaces which are inaccessible to the eyes of the spectator, but which animate the play's exotic phantasies through the work of imagination.

At the time, the use of stage machinery in order to create strong visual effects and to stimulate the spectator's sense perceptions was becoming popular.

Machinery allowed the reproduction of some sound effects, such as the sound of trumpet, or of human voices, horse shuffling, once reproduced verbally, which belonged at the same time to a fictional and real world knowable and known.

Drama, through the heightened use of verbs of vision or sounds and voices, met the need to show the events, to attract the audience (and the reader) towards the written texts. In so doing, the barrier between fiction and reality could be brought down and the audience could be consciously involved in the performance, it could be made aware of its meanings and enjoy it both sensually and intellectually.

At a time of significant political and spiritual uncertainty, drama commemorates the most important historical and religious events. It not only celebrates the prince or the primacy of faith, but offers itself to the audience as a cathartic opportunity to participate in the events presented on stage. Thus, theatre becomes not simply an ideological apparatus (Foucault) of the court, but also the lieu of "consolation" from worldly concerns. The courtier sees his reflection in the mirror image of the world offered on stage: In addition, he envisages the solution to his worries and the prospect of success.

As a result, the relationship between the stage and the text is altered, since the celebratory or cathartic will of the theatre enables the material spaces of the scene, possessing a universal valence, to take on a semantic value and to transcend the materiality of actual life. Consequently, the physical and material constraints of the stage space, and of the lack of stage objects that can better replicate everyday reality, are transcended.

The issue of spatial depth becomes paramount, and, as in the case of comedy, it determines not just the physical arrangement and semantic traits of the action, but also the verisimilar reproduction of the acting spaces.

For this reason, in addition to the necessity of conceiving a perspective view of the scene, the antithesis outdoor/indoor and inside/outside has to be solved, not simply to define the scenic space and the locus of the performance, but also to widen the observation point of the spectator beyond the stage front, in order to enable him/her to reach with the eye the innermost spaces, which correspond not simply to physical spaces, but to psychological and spiritual ones. $^{20}$

\footnotetext{
${ }^{20}$ Si tratta di quegli spazi denominati, rispettivamente, "spazio extrascenico”, cioè "non visibile che si immaginava al di là delle esioidoi" e "spazio retroscenico", cioè: "la porzione di spazio dell'orchestra non visibile agli spettatori a causa della presenza di un diaframma”. A questi si aggiunge: lo "spazio extrascenico lontano", quello "spazio fisico esistente al di là delle esioidoi", evocante "luoghi molto lontani, per i quali non era immaginabile alcuna forma di contatto diretto con il luogo raffigurato sulla scena"; infine lo "spazio extrascenico adiacente" che rappresentava "luoghi adiacenti allo spazio scenico, quelli cioè che lo spettatore doveva immaginare come collocati più vicino alle esioidoi” (Di Benedetto \& Medda, 1997, pp. 34-39).
} 


\section{A “Sacred Inner Theatre"}

The relationship between the spectator and the stage is thus transformed by the act of seeing which provides a sensible counterpart to the exercise of memory and imagination, upon which such a relationship is founded. The spectator can intimately engage with the performance (s)he is watching thanks to the interaction between his/ her perceptive, imaginative, cultural background, and memory. Such an interaction is particularly evident in the Jesuitical and Baroque theatre, where a visually rich staging urges the spectator to de-codify its multiple ethical and aesthetic meanings.

Given its numerous perspectives, fifteenth-and-sixteenth century Jesuitical theatre characterises itself for its exceptional theatrical relationship whereby the spectator is not simply the pivot of the spectacle but, in a game of mirrors, he becomes the spectacle himself, as he is at the same time the receiver and the creator of the religious message. At a time where the image of "God/Spectator" observing and judging the world dominates, the eyes, the act of seeing, understood as a gnoseological act, are chosen as the ultimate instruments of knowledge, as testified by seminal Jesuitical writings, such as Ignatius of Loyola's Spiritual Exercises (1548), Emanuele Tesauro's Aristotelian Telescope (1654) and Moral Philosophy (1670).

Images play a central role in Loyola's work, to the extent that they preconize his "radical imperialism of the image” over language (Barthes, 1989, p. 66). Arguably, the 16th and the 17th centuries celebrate the primacy of sight. Sight is now seen as the perceptive sense par excellence, the sense which allows man to enter fully in touch with the world, supplanting touch and hearing which were the predominant perceptive senses in the Middle Ages. However, in the case of liturgical theatre, seeing as a source of knowledge is part of a more complex "apparato", in which hearing and sight, ethical action and hedonistic practice, spectacle and religious indoctrination interact. This interaction originates in the passage from myth to religion, in the synthesis between religiosity and ancient knowledge which the theatrical experience of the Society of Jesus encompasses.

Visual illusions are one of the key elements of sixteenth century performances, as they sustain and complete the adaptation from text to stage, and make it possible to render more real and tangible the objects, the places and spaces that could not be easily reproduced on stage and, thus, be experienced by the audience.

The audience is asked to perform an act of imagination and a rhetorical effort in order to reproduce in its mind, through memory and the visual and sensorial effects of the performance, the places in which the fictional events take place.

This act of memory and imagination the audience performs resembles the act of memory (and of the art of memory) that Igniatius of Loyola describes in his Spiritual Exercises. The author in this text, which is primarily a book of prayers, describes a procedure to elaborate a series of mental images through the visual technique of the composition of place, that is the mental representation (as the one that takes place on stage) of the actual "physical place", where meditation occurs. ${ }^{21}$

It is not a material, but a mental and spiritual approach to the subject of contemplation which produces a

\footnotetext{
${ }^{21}$ According to Roland Barthes: "The Ignatian image isnot a vision, it is a view, in the sense this word has in graphicart [...] this 'view' must be captured in a narrative sequence [...] These views (stretching the meaning of the word, since it entails all the units of image-reservoir perception ) can 'frame' tastes, odors, sounds, or feelings, but it is the 'visual' sight, one might say, which receives all of Ignatius's attention. Its subjects are various: a temple, a mountain, a vale of tears, the Virgin's chamber, a warrior camp, a garden, a sepulcher, etc.; its detail is painstaking (consider the length of the road, its width, if it passes through a plain or across valleys and hills, etc.). These views, whose suggestion in principle precedes every exercise, are the famous composicionviendo el lugar. The composition of place was supported by a dual tradition. First, a rhetorical tradition; the second, sophistic or neo-rhetorical Alexandrine, had consecrated place description under the name topography" (Barthes, 1989, p. 55).
} 
"sacred, inner theatre" in the imaginary and the sensible domain of those who meditate (Pfeiffer, 1994, p. 32). This type of theatre is made up of ephemeral images and settings which ideally recall the stage space. "Divine Interlocution" and the "path of fantasy" that Ignatius imagines (Barthes, 1989, pp. 45, 74), graft onto the visual and visible dimension of the performance, revealing a space which originally conceived of as an inner dogmatic space, subsequently becomes explicit and extrinsic, created to show the spectator the spiritual motifs and content of the text presented on stage. Within the Ignatius' theoretical purview, the fictionality of the places, of the actions and of the characters is grounded in the "tres Binarios de hombres", a mental process whereby the spectator is able to see the characters, hear what they are saying and observe what they are doing, that is they cognitively elaborate an action that can be objectified.

The act of creating mental images, prescribed by the Spiritual Exercises, is an assemblage of images in the filmic sense, whereby the first part is a "rumination" followed by the "recapitulation". Then, Ignatius elaborates "an excerpting of the Gospel narrative", from which a narrative constituted by images emerges with the help of rhetorical techniques such as suspense and reference. This act of memory gives rise to the "mysteries", a Christian narrative taking on "a theatrical quality which relates them to the medieval mysteries. They are 'scenes' the exercitant is called upon to live out, as in a psychodrama” (Barthes, 1989, p. 61).

The exercitants have to internalize the life of the character and subsequently externalize it through their interpretations, by also establishing a relationship with materiality. What is significantly and necessarily objectified is the body. The corporeality of the body has to establish a relationship with the image and substantiate the representation, become the representation, become Christ. "The body's deictism is reinforced by the way it is transmitted, the image. The image is in fact by nature deictic, it designates, it does not define; it always contains a residue of contingency, which can merely be indicated” (Barthes, 1989, p. 62).

The image of the body, thanks to its evocative power, brings the object of imagination (and of the image) onto a material plane. The body of Christ and the cross facilitate the identification between the exercitant and the Passion of Christ. ${ }^{22}$ The imaginative act moves the action from a mental to an objective dimension defined by the familiar mechanisms of the theatre, of the staging, where the exercitant and the main character coincide. Thanks to mimesis, i.e. the founding element of the theatrical representation, what is represented on stage becomes an imitation of the real, from which verisimilitude arises. Following Loyola's prescriptions, corporeality has to support the mimetic process, as a result of which the "exercitant is continually required to imitate twice, to imitate what he imagines: to think of Christ 'as though one saw Him eating with His disciples, His way of drinking, of looking, of speaking; and try to imitate Him”' (Barthes, 1989, p. 52). The exercitant has to submit to a process of "reviviscence" which anticipates Stanislavskji's system. ${ }^{23}$

Hellish or heavenly characters, places and images are evoked thanks to the representation of the body which, in turn, brings about a polysemous, hallucinatory action. At the same time, the mimetic regime of imagination forces the spectator to evoke, in his/her mental scene, the weather, the garments, the food, the way in which Christ sits at the table of the Last Supper, his way of drinking, eating, speaking, and seeing (Barthes, 1989, p. 54).

\footnotetext{
${ }^{22}$ This is a prefiguration of neuroscience, and specifically of the functioning of mirror neurons.

${ }^{23}$ This system is based on the study of the character's psychology in order to establish an emotional affinity between characters and actors. Subsequently, actors are required to internally re-elaborate the emotions of the character in order to portray them onstage. To this purpose, Stanislavskij developed a series of exercises which aimed at stimulating the emotions to be portrayed which he subsequently collected in his An Actor's Work: A Student's Diary (1938) and Building A Character, published posthumously.
} 
Although they may appear as meticulously conceived, such images are not really as detailed. Indeed, the exercitant only uses a series of mental sketches that he has to complete by means of his imagination. This mechanism of "subtraction" recalls the Renaissance concept of the "sprezzatura", which, following Baldassar Castiglione, "as a picture of the court of Urbino, not by the hand of Raphael or 'Michelangelo', but of a humble painter, who knows only how to trace the chief lines, and cannot adorn truth with bright colouring or by perspective art make that which is not seem to be” (Castiglione, 1903, p. 2).

To meditate, to interiorize and to represent subjectivity as the object of imagination, and to comprehend through the latter, are all actions which require the same skills of an actor or a director, in order to transfer such knowledge to the spectator (who is the recipient of such a process and who, in the case of meditation, is the same subject). The spectator intervenes in the representation and through his/her imagination understands the meaning of the action and of the places represented, (s)he feeds on its mysticism, (s)he is conquered by it.

Nevertheless, as Roland Barthes has written, the model provided by the Exercises is "much less mystical than rhetorical"; the author develops a "language of interrogation [...] mantic art, the art of divine consultation" (Barthes, 1989, pp. 45-46), which refers back to a dialogic dimension not unlike that of the theatre, where the assemblage of actions obeys certain rhetorical criteria, such as those of the invention and of the dispositio. ${ }^{24}$

The need to activate the imagination, as required by the hermeneutic experience of the Exercises, requires such exercises "to be practiced" rather than simply read. The dynamic connotation of the Ignatian writing is thus exalted, demanding of the reader that he overcomes the passivity of reading.

Thus, the exercitant is at the same time the actor and the spectator of his own reading which is acted, also thanks to his "mobile point of view". He completely abandons himself to his reading and its content, in a position of "trust" - similar to the one that the theatrical relationship establishes—but transforms the text in a paratext/apparato functional to the action (Spadaro, 2004).

Following the criteria illustrated here, in order for meditation to be effective it has to take place in an extraordinary time which differs from the ordinary time of everyday actions. Although meditation is a daily activity, because of its spiritual nature, it has to configure itself as an extraordinary exercise. Within such a reflexive mode, the exercitant becomes the character he is impersonating and thus redesigns the spaces, the narrative and the dimensions of thought within ordinary time.

To see what lacks material representation on the stage is, therefore, a truly creative act that the spectator performs the moment when, through his/her imagination, (s)he has to remember what is absent from the scene. As the present paper has argued, the Renaissance spectator performs this act; through the use of rhetorical mnemotechnics and the interaction with the figurative arts, (s)he locates himself/herself in an ideal place where the stage space becomes the lieu of the stereoptics. As a result, as it has been shown, the process of creation and that of consumption of the vision originates, first and foremost, in drama. Thus, the dramatic text allows us to track the psychological, aesthetic and anthropological mechanism proper of the vision, including the understanding of images that derive from words, from the point of view of both the playwright and the spectator-listener in a direct relationship of cause and effect.

Religious, and especially Jesuitical, theatre, whose dramatic experience offers a further example of the correspondence between words and images, testifies to such a visual power of the theatre.

\footnotetext{
${ }^{24}$ As discussed in Fanelli C. (2011), Con la bocca di un'altra persona. Retorica e drammaturgia nel teatro del Rinascimento, Bulzoni, Roma.
} 


\section{Conclusion}

The present article has offered a series of examples to demonstrate how the visual apparatus devised by the sixteenth-century scenic designers produced a functional interaction with the rhetorical dimension conceived by the playwrights. As a result, such an interaction brings about a strict correlation between the scenic space, as the lieu of vision, and dramaturgy as an instrument of vision.

Shakespeare's theatre offers a significant instantiation of the figurative value of words. Such a quality is not simply proper of the Bard's work, but is typical of Elizabethan theatre, in which scenic design is almost entirely absent. The circular stage which allows the spectators to occupy all three sides of the space around the stage, by standing in the yard or sitting in the gallery, significantly differs from the perspective scene proper of Italian theatre with its frontal view of the stage. This contributes to the absence of the scenic design and produces considerable differences in the theatrical experience of the spectators. Consequently, in the absence of the scenic design, the construction of the theatrical relationship relies on the actors' ability and on the text of the play. Within such a context, words do not simply tell a story, but evoke feelings, and above all images by means of the rhetorical devices which one may call, using Masolino D’Amico's definition, "verbal scenic design". ${ }^{25}$

As the paper has argued, the Italian Renaissance theatre develops a different relationship between the scenic space and the spectator, as a result of which the stage becomes the place where image and imagination come together in the performance. The perspectival scenery representing the city ensures the mimetic development and the celebration of the court and its prince, the "visual" contents of the text allow the spectators to transcend the physical boundaries of the places represented on stage.

Thus, the prologue in the Calandria by Bibbiena provides the opportunity to journey around the roofs of the houses in Florence and encounter the people about to take part into the feast. Similarly, the prologue of the Madragola illustrates the relationship existing between the painted scene and the spectator's imagination. Some Renaissance treaties such as Giraldi Cinzio's, Ingegneri's and Trissino's assert the need to provide a visual representation of the written text since, as Aristotle affirmed in his Poetics, the poet is an 'eyewitness' of the actions he invents.

Such a need to see, to show that which is not represented on stage, characterises tragedy as well. Tragedy has to elicit the emotions of the spectator in order to absolve to its cathartic function. Therefore, the mnemonic evocation of places and actions far from the scene stimulate this imaginative mechanism by means of which the spectator empathises with the action on stage.

Naples in Giordano Bruno's The Candle Bearer reconfigures the image of the city, separated from courtly celebration. In this philosophical comedy, Bruno inserts his cosmological reflections. The city, whose toponyms are accurately reproduced, is full of life and is evoked in its nightly dimension, it escapes the Aristotelian rules in its being densely populated, pulsating with life.

If, for the courtesan, the scene was an instrument for observing the city and the magnificence of its prince, in Bruno, the urban dimension, plunged into darkness, becomes the place from which one can lift his/her own eye to sky and observe the universe, overcoming the physical and architectonic boundaries of the city. Jesuitical theatre, which draws on the horror characterising Seneca's tragedies and which amply utilises verbs of sight, also makes extensive use of imagination in its effort to communicate a religious message through drama.

${ }^{25}$ D’Amico, M. (2007), Scena e parola in Shakespeare, Roma: Edizioni di storia e letteratura. 
Barthes' reading of Ignatius of Loyola's Spiritual Exercises has allowed us to demonstrate how mysticism and prayer require the help of imagination which, in turn, enables the exercitant to produce an imaginary theatrical scene in his mind. This exercise, which arises out of individual meditation, takes on a collective dimension in the theatrical "experimentation" of Jesuitical colleges, where the interaction between theatrical scene and visual writing is exalted, in keeping with the pictorial and architectural practice of the Order.

\section{References}

Alighieri, D. (1985). The Divine comedy. (Vol. II). Purgatory. (Translated with an Introduction, Notes and Commentary by M. Musa) (p. 111). Harmondsworth: Penguin.

Aretino, P. (2010). Talanta, in Teatro (Plays). Vol. V t. 2 dell'Edizione Nazionale delle Opere di Pietro Aretino, a c. di G. Rabitti, E. Garavelli, C. Bocca. (p. 450). Roma: Salerno Editore.

Ariani, M. (1974). Tra classicismo e manierismo. Il teatro tragico del Cinquecento (Between classicism and mannerism. The tragedy in fifteenth century theatre). Firenze: Olschki.

Aristotle. (1941). “De Memoriaet Reminiscentia (On Memory and Remiscence). In R. McKeon (Ed.), The basic works of Aristotle (p. 608). New York: Random House.

Aristotle. (n.d.). Poetics. Retrieved from http://classics.mit.edu/Aristotle/poetics.1.1.html

Attolini, G. (1988). Teatro e spettacolo nel Rinascimento (Theatre and performance in the Renaissance) (pp. 24-30). Bari: Laterza.

Barthes, R. (1989). Sade, Fourier, Loyola. (R. Miller, Trans.). Berkeley and Los Angeles: University of California Press.

Bruno, G. (2004), Opere italiane (Italian works). Torino: UTET.

Castelvetro, L. (1967). Poetica d'Aristotele vulgarizzataet sposta (A reading and commentary of Aristotle's poetics). Munchen: Wilhelm Fink Verlag.

Castiglione, B. (1903). The book of the courtier (L. E. Opdycke, Trans.). New York: Scriber.

Cruciani, F. (1986). Per lo studio del teatro rinascimentale: la festa (The Festa. A study of the Renaissance theatre). In F. Cruciani and D. Seragnoli, Il teatro italiano nel Rinascimento (The Italian renaissance theatre) (pp. 31-45). Bologna: IL Mulino.

D’Amico, M. (2007). Scena e parola in Shakespeare (Stage and word in Shakespeare). Roma: Edizioni di storia e letteratura.

De Sommi, L. (1968). Quattro dialoghi in materia di rappresentazione scenic (Four dialogues on theatrical representation) (p. 258). Milano: Il Polifilo.

Del Lungo, I. (1875). La recitazione dei Menaechmi in Firenze e il doppio prologo della Calandrain (Acting in The Menaechmi in Florence and the double prologue in the Calandra). Archivio Storico Italiano, S. III, XXIII, 341-51.

Di Benedetto, V., \& Medda, E. (1997). La tragedia sulla scena. La tragedia greca in quanto spettacolo teatrale (Tragedy on stage. Greek tragedy as spectacle). Torino: Einaudi.

Doni, A. F. (1928). I Marmi (The marbles) (E. Chiorboli, Ed.). Bari: Laterza.

Fanelli, C. (2011). Con la bocca di un'altra persona. Retorica e drammaturgia nel teatro del Rinascimento (Speaking in someone else's voice. Rhetoric and dramaturgy in the Renaissance theatre). Roma: Bulzoni.

Fanelli, C. (September 2012). Il secondo Prologo della Calandria. Vedere con gli occhi della mente (The Second Prologue of the Calandria. Seeing with the eyes of the mind). (Paper presented at La letteratura degli italiani 4. I letterati e la scena, Atti del XVI Congresso Nazionale Adi, Sassari-Alghero, 19-22 September, G. Baldassarri, V. Di Iasio, P. Pecci, E. Pietrobonand, F. Tomasi (Eds. 2014), Roma, Adi editore, (ISBN: 978-88-907905-2-2).

Ferroni, G. (1986). Il teatro e la corte (The theatre and the court). In F. Cruciani, Il teatro italiano nel Rinascimento (The Italian theatre in the Renaissance) (pp. 177-88). Bologna: IL Mulino.

Foucault, M. (2009). “What is an Apparatus?” In G. Agamben, What is an apparatus and other essays (p. 3) (D. Kishik \& S. Pedatella, Trans.). Stanford: Stanford University Press.

Foucault, M. (October 1984). "Of other spaces: Utopia and Heterotopia”. (J. Miskowiec, Trans.). In Architecture /Mouvement/ Continuité. Retrieved from https://www.web.mit.edu/allanmc/www/foucault1.pdf

Gareffi, A. (1991). La scrittura e la festa. Teatro, festa e letteratura nella Firenze del Rinascimento (The writing, festa and literature in Renaissance Florence). Bologna: IL Mulino.

Giraldi Cinzio, G. B. (1996). Selene. An Italian Renaissance tragedy. (Edited with Introduction, Notes, and Glossary by P. Horne). Lewinston/Queenston/Lampeter: Edwin Mellen Press.

Guidotti, A. (2002). Scenografie di pensieri. Il teatro del Rinascimento fra progetto e sperimentazione (The scenic design of thought. The Renaissance theatre as project and experimentation). M. P. Fazzi, (Ed.). Lucca: M. P. Pacini Fazi. 
Ingegneri, A. (1974). Della poesia rappresentativa e del modo di rappresentare le favole sceniche (On representational poetry and on the way of representing visual tales). In F. Marotti, Lo spettacolo dall'Umanesimo al Manierismo (The spectacle from humanism to the Renaissance) (p. 95). Milano: Feltrinelli.

Krautheimer, R. (1994). Le tavole di Urbino, Berlino e Baltimora (The Urbino, Berlin and Baltimora tables). In H. Millon and V. Magnano Lampugnani, Rinascimento. Da Brunelleschi a Michelangelo. La rappresentazione dell'architettura (From Brunelleschi to Michelangelo: The representation of architecture) (pp. 233-257). Milano: Bompiani.

Krautheimer, R. (June 1948). The tragic and the comic scene in the Renaissance: The Baltimore and Urbino Panels. Gazette des Beaux-Arts, VI(XXXIII), 327-346.

Machiavelli, N. (2001), Teatro. Andria, Mandragola, Clizia (Plays. Andria, The Mandrake Root, Clizia). G. Davico Bonino, (Ed.). Torino: Einaudi.

Padoan, G. (1985). La Calandra. Commedia elegantissima per Messer Bernardo Dovizi da Bibbiena (The Calandra. An elegant comedy for Mr Bernardo Dovizi from Bibbiena). Padova: Antenore.

Panofsky, E. (1991). Perspective as "symbolic form”. (C. S. Wood, Trans.). New York: Zone Books.

Pfeiffer, S. J. H. (1994). La radice spirituale dell'attività teatrale della Compagnia di Gesù negli "Esercizi spirituali” di Sant'Ignazio (The spiritual root of the theatrical activity of the society of Jesus in "The Spiritual Exercises" of Ignatius of Loyola). (Paper presented at I Gesuiti e i Primordi del Teatro Barocco in Europa, Atti del XVIII Convegno Internazionale del Centro Studi sul teatro medioevale e rinascimentale, Roma 26-29-30 ottobre, edited by M. Chiabò and F. Doglio, Torre d’Orfeo, Roma).

Quintilian, M. F. (1968). The Institutio Oratoria of Quintilian (Quintilian's institutes of oratory). (Vols. III-IV, H. E. Butler, Trans.). London: Heinmann.

Sabbatino, P. (1998). Giordano Bruno e la “mutazione" del Rinascimento (Giordano Bruno and the "mutation” of the Renaissance). Firenze: Olschki.

Serlio, S. (1545). Isettelibridell'architettura (The Seven Books of Architecture). Paris: Various Publishers.

Shakespeare, W. (1955). King Henry v. In J. D. Wilson, (Ed.). The Cambridge Dover Wilson Shakespeare. Cambridge: Cambridge University Press.

Shakespeare, W. (1980). Hamlet. T. J. B. Spencer, (Ed.). Harmondsworth: Penguin, act I sc. I. 63.

Spadaro, S. I. A. (April 2004). La lettura come immersione interattiva. Tra "Esercizi spirituali” e "Realtà virtual” (Reading as an interactive exercise. Between the "Spiritual Exercises” and "Virtual Reality”). La Civiltà Cattolica, 155, 42.

Trissino, G. G. (1969). La poetica (Poetics). München: Whielelm Fink Verlag.

Warburg, A. (1966). La rinascita del paganesimo antico (The return of ancient paganism). Firenze: La Nuova Italia.

Zorzi, L. (1977). Il teatro e la città. Saggi sulla scena italiana (The theatre and the city. Essays on the Italian theatrical scene). Torino: Einaudi. 